\title{
Penerapan Algoritma Klasifikasi Classification And Regression Trees (CART) untuk Diagnosis Penyakit Diabetes Retinopathy
}

\author{
Pungkas Subarkah \\ Program Studi Informatika,Fakultas Ilmu Komputer, Universitas Amikom Purwokerto \\ E-Mail : subarkah@amikompurwokerto.ac.id
}

\begin{abstract}
ABSTRAK
Penyakit diabetic retinopathy atau DR adalah salah satu komplikasi penyakit diabetes yang bisa menyebabkan kematian bagi penderitanya. Komplikasi tersebut berupa kerusakan pada bagian retina mata.Tingginya kadar glukosa dalam darah adalah penyebabpembuluh darah kapiler kecil menjadi pecah dan dapatmenyebabkan kebutaan. Retinopati diabetes diawali dengan melemah atau hancurnya kapiler kecil di retina, darah bocor yang kemudian menyebabkan penebalan jaringan, pembengkakan, dan pendarahan yang luas. Penelitian ini bertujuan untuk menganalisis diagnosis penyakit diabetes retinopathy. Algoritma Classification And Regression Trees (CART) merupakan salah satu algoritma klasifikasi dengan menggunakan dataset diambil dari UCI Repository Learning diperoleh dariUniversitas Debrecen, Hongaria, yang terdiri dari data pasien terindikasi penyakit diabetes retinopathy dan normal penyakit diabetes retinopathy. Metode yang digunakan dalam penelitian ini yaitu identifikasi masalah, pengumpulan data, tahap pre-processing, metode klasifikasi, validasi dan evaluasi serta penarikan kesimpulan. Adapun metode validasi dan evaluasi yang digunakan yaitu 10-cross validation dan confusion matrix.Dari hasil perhitungan yang telah dilakukan, maka didapatkan hasil akurasi pada algoritma CART sebesar $63.4231 \%$, dengan nilai precision $0.64 \%$, nilai Recall $0.634 \%$, dan nilai $F$-Measure $0,634 \%$.
\end{abstract}

Kata Kunci: Diabetes Retinopathy, Klasifikasi, CART.

\begin{abstract}
Diabetic Retinopathy or DR is a complication of diabetes that can cause death for sufferers. These complications are damage to the retina of the eye. High blood sugar levels cause small capillaries to rupture and can cause blindness. Diabetic retinopathy begins with a decrease or destruction of small capillaries in the retina, blood leak which then causes tissue thickening, swelling, and extensive bleeding. This study attempts to analyze the diagnosis of diabetic retinopathy. Classification Algorithms And Regression Trees (CART) is one algorithm that uses a dataset taken from the UCI Learning Repository obtained from Debrecen University, which consists of patient data indicated by diabetic retinopathy and normal retinopathy diabetes. The method used in this research is problem collection, data collection, pre-processing, collection methods, validation and evaluation as well as gathering conclusions. The validation and evaluation methods used are 10-cross validation and confusion matrix. From the results of calculations that have been done, the accuracy of the CART algorithm is obtained at $63.421 \%$, with a precision value of $0.64 \%$, a Recall value of $0.634 \%$, and a value of F-Measures $0.634 \%$.
\end{abstract}

\section{Keywords: Diabetes Retinopathy, Classification, CART.}

Author Korespondensi (Pungkas Subarkah)

Email : subarkah@amikompurwokerto.ac.id

\section{PENDAHULUAN}

Penyakit diabetic retinopathy atau DR adalah salah satu komplikasi penyakit diabetes yang bisa menyebabkan kematian bagi penderitanya. Komplikasi tersebut berupa kerusakan pada bagian retina mata. Tingginya kadar glukosa dalam darah adalah penyebab pembuluh darah kapiler kecil menjadi pecah dan dapatmenyebabkan kebutaan. Retinopati diabetes diawali dengan melemah atau hancurnya kapiler kecil di retina, darah bocor yang kemudian menyebabkan penebalan jaringan, pembengkakan, dan pendarahan yang luas [1]. Penyakit ini pada umumnya akan berdampak secara langsung pada terganggunya penglihatan penderita dan apabila terlambat ditangani maka akan menyebabkan penderita mengalami kebutaan secara permanen. DR hingga saat ini masih sulit disembuhkan karena mayoritas penderita melakukan pemeriksaan di saat kondisi penyakit telah memasuki tahap berbahaya. Hal ini dikarenakan sifat dari penyakit DR ini yang 
tidak menunjukkan gejala yang terlihat bila masih pada tahap awal [2].

Penyakit ini merupakan salah satu komplikasi mikrovaskular diabetes melitus dengan angka prevalensi yang cukup tinggi. Berdasarkan data penelitian yang dilakukan di beberapa daerah di Indonesia, diperkirakan prevalensi retinopati diabetik sebesar 42,6\%. Setidaknya akan ditemukan 24.600 orang dengan retinopati diabetik dan sekitar $10 \%$ dari jumlah tersebut mengalami kebutaan. Jumlah ini diperkirakan akan meningkat pada tahun 2030 dengan estimasi 98.400 orang menderita diabetes dan sekitar 11.000 orang diantaranya mengalami kebutaan. Mengingat sebagian besar kebutaan akibat diabetik retinopati merupakan kondisi yang permanen dan tidak dapat diobati, maka pencegahan dan pengobatan menjadi hal yang penting [3]. Efek visual dari kebocoran digambarkan dengan adanya perubahan pada retina seperti perubahan venous, cotton wool spots, mikroaneurisma, hard exedute dan pendarahan [4].

Menurut International Diabetes Mellitus Federation (IDF) Atlas 2017: epidemi Diabetes Melitus di Indonesia masih menunjukkan kecenderungan meningkat. Indonesia adalah negara peringkat ke-enam di dunia setelah Tiongkok, India, Amerika Serikat, Brazil dan Meksiko dengan jumlah penderita Diabetes Melitus usia 20-79 tahun sekitar 10,3 juta orang. Riset Kesehatan Dasar (Riskesdas) juga memperlihatkan peningkatan angka prevalensi Diabetes Melitus yang cukup signifikan, yaitu dari $6,9 \%$ di tahun 2013 menjadi 8,5\% di tahun 2018; sehingga estimasi jumlah penderita Diabetes Melitus di Indonesia mencapai 22 juta orang[5]. Diagnosis dini pada penyakit diabetes retinopathy dapat dilakukan dengan metode data mining. Dimana proses pada metode data mining bertujuan untuk menguraikan temuan baru di dalam dataset dan menjelaskan suatu proses yang menggunakan teknik statistik, matematis, artificial intelligence, dan machine learning untuk melakukan ekstrak dan identifikasi informasi yang bermanfaat dan pengetahuan yang terkait dari database tersebut.

Salah satu fungsi utama data mining adalah klasifikasi. Klasifikasi banyak digunakan untuk menentukan keputusan sesuai pengetahuan baru yang didapat dari pengolahan data lampau menggunakan perhitungan suatu algoritma. Teknik klasifikasi dapat diterapkan dalam semua bidang misalnya dalam bidang kesehatan [6], serta banyak digunakan dalam bidang lain. Dalam dataset klasifikasi terdapat satu atribut tujuan atau dapat pula disebut dengan atribut label. Atribut inilah yang akan dicari dari data baru dengan dasar atribut lain pada data lampau. Banyaknya atribut dapat mempengaruhi performansi suatu algoritma [7].

Algoritma Classification And Regression Trees (CART) adalah satu metode atau algoritma dari salah satu teknik ekplorasi data yaitu teknik pohon keputusan [8]. Metode ini dikembangkan oleh Leo Breiman, Jerome H.Friedman, Richard A. Olshen dan Charles J. Stone sekitar tahun 1980. CART merupakan metodologi statistik non-parametrik yang dikembangkan untuk topik analisis klasifikasi, baik untuk variabel respon kategorik maupun kontinu. Metode ini merupakan metode yang biasa diterapkan suatu himpunan data yang mempunyai jumlah besar, variabel yang sangat banyak dan dengan skala variabel campuran melalui prosedur pemilahan biner [9]. Kelebihan dari algoritma CART adalah metode yang bersifat non-parametrik atau cocok digunakan untuk data yang berjenis numeric. CART tidak memerlukan variabel yang akan dipilih terlebih dahulu dan menghasilkan invariant untuk transformasi variabel yang independen [10]. Pada klasifikasi algoritma CART, sebuah record akan diklasifikasikan ke dalam salah satu dari sekian klasifikasi yang tersedia pada variabel tujuan berdasarkan nilainilai variabel prediktornya [11]

Penelitian ini bertujuan untuk menganalisis penyakit diabetes retinopathy menggunakan dataset yang diperoleh dari UCI repository machine learning dan dibuat oleh Universitas Debrecen, Hongaria, untuk melakukan klasifikasi diagnosis penyakit diabetes retinopathy. Peneliti menggunakan algoritma klasifikasi yaitu CART.

\section{METODELOGI}

Tahapan penelitian dilakukan untuk mempermudah dalam melakukan penelitian. Desain penelitian analisis algoritma klasifikasi CART untuk diagnosis penyalit diabetes retinopathy dilihat pada gambar 1 . 


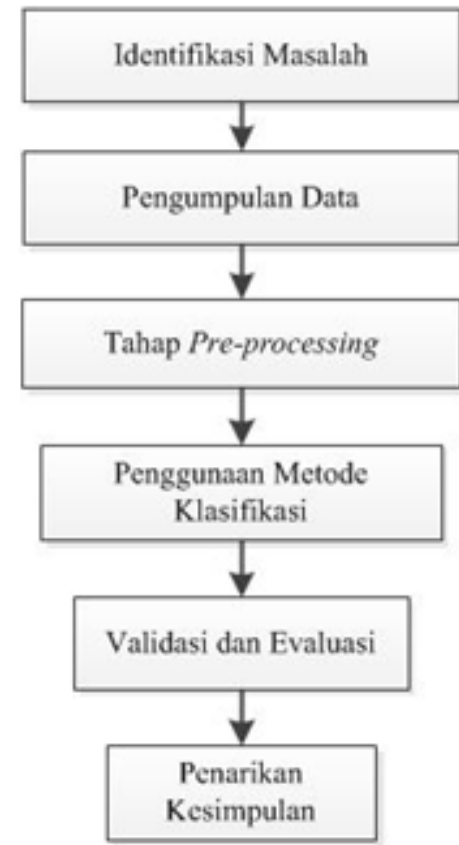

Gambar 1. Tahapan Penelitian

\subsection{Identifikasi Masalah}

Pada tahapan ini dilakukan untuk mengetahui permasalahan serta metode yang sesuai sehingga dapat ditentukan poin-poin untuk target diagnosis penyakit diabetes retinopathy.

\subsection{Pengumpulan Data}

Dalam tahapan ini pengumpulan data menggunakan data sekunder yang digunakan, diambil dari database UCI Repository. Dataset terdiri dari 1151 record, yang memiliki 19 attribute (18 attribute dan 1 attribute target). Attribute target terdiri dua output yaitu normal diabetes retinopathy dan terindikasi diabetes retinopathy [12]. Kedua output pada class attribute ini akan digunakan sebagai output data penyakit diabetes retinopathy. Penjelasan mengenai atribut diabetes retinopathy, dapat dilihat pada tabel 1 dan tabel 2 .

Tabel 1. Attribut Pada DatasetDiabetes Retinopathy

\begin{tabular}{|c|l|}
\hline Nama & \multicolumn{1}{|c|}{ Informasi } \\
\hline Attribute 0 & Hasil biner pada kualitas penilaian \\
\hline Attribute 1 & Hasil biner pada pra-skrining \\
\hline Attribute 2 & Hasil deteksi MA \\
\hline Attribute 3 & Hasil deteksi MA \\
\hline Attribute 4 & Hasil deteksi MA \\
\hline Attribute 5 & Hasil deteksi MA \\
\hline Attribute 6 & Hasil deteksi MA \\
\hline Attribute 7 & Hasil deteksi MA \\
\hline Attribute 8 & Hasil normalisasi pada eksudat \\
\hline Attribute 9 & Hasil normalisasi pada eksudat \\
\hline Attribute 10 & Hasil normalisasi pada eksudat \\
\hline
\end{tabular}

\begin{tabular}{|c|l|}
\hline Attribute 11 & Hasil normalisasi pada eksudat \\
\hline Attribute 12 & Hasil normalisasi pada eksudat \\
\hline Attribute 13 & Hasil normalisasi pada eksudat \\
\hline Attribute 14 & Hasil normalisasi pada eksudat \\
\hline Attribute 15 & Hasil normalisasi pada eksudat \\
\hline Attribute 16 & $\begin{array}{l}\text { Jarak Euclidean pada pusat manula dan } \\
\text { pusat cakram optic }\end{array}$ \\
\hline Attribute 17 & Diameter cakram optik \\
\hline Attribute 18 & $\begin{array}{l}\text { Hasil biner pada klasifikasi berbasis } \\
\text { AM/FM }\end{array}$ \\
\hline Target_Attrib & $\begin{array}{l}\text { Label kelas. 1 = mengandung tanda-tanda } \\
\text { DR (label akumulatif untuk kelas } \\
\text { Messidor 1, 2, 3), kelas. 0 = tidak ada } \\
\text { tanda-tanda DR. }\end{array}$ \\
\hline
\end{tabular}

Tabel 2. Jumlah Dataset Berdasarkan Class

\begin{tabular}{|c|c|c|}
\hline No & Jenis Klasifikasi & $\begin{array}{c}\text { Jumlah Record } \\
\text { Dataset }\end{array}$ \\
\hline 1 & Contains Signs & 611 \\
\hline 2 & No Signs & 540 \\
\hline \multicolumn{2}{|c|}{ Jumlah } & $\mathbf{1 1 5 1}$ \\
\hline
\end{tabular}

\subsection{Tahap Pre-Processing}

Pada tahapan ini dilakukan suatu proses seleksi data dengan tujuan untuk mendapatkan data yang bersih dan siap digunakan sebagai bahan penelitian. Tahap pre-processing data meliputi identifikasi dan pemilihan atribut (attribute identification and selection), penanganan nilai atribut yang hilang atau atribut yang tidak lengkap (handling missing values) dan proses diskretisasi nilai.

\subsection{Penggunaan metode klasifikasi}

Metode yang peneliti gunakan yaitu algoritma CART, dari hasil confusionmatrix dapat dihitung nilai precision, recall dan F-Measure [13]. Rincian confusion matrix dapat dilihat pada tabel 3.

Tabel 3. Confusion Matrix

\begin{tabular}{|c|c|c|}
\hline $\begin{array}{c}\text { Correct } \\
\text { classification }\end{array}$ & Classification as \\
\cline { 2 - 3 } & + & - \\
\hline+ & True positives & $\begin{array}{c}\text { False } \\
\text { positives }\end{array}$ \\
\hline- & False positives & $\begin{array}{c}\text { True } \\
\text { negatives }\end{array}$ \\
\hline
\end{tabular}

Adapun rumus perhitungan dari sebuah precision, recalll dan F-Measure dari sebuah accuracy [13], dapat dilihat pada persamaan dibawah ini.

$$
\begin{aligned}
& \text { Precision }=\frac{T P}{T P+F P} \\
& \text { Recall }=\frac{T P}{T P+F N}
\end{aligned}
$$


$F$-Measure $=\frac{2 \times \text { precision } \times \text { recall }}{\text { precision }+ \text { recall }}$

Accuracy $=\frac{T P+T N}{T P+F P+F N+T N}$

\subsubsection{Validasi dan Evaluasi}

Dalam tahap ini dilakukan validasi dan evaluai serta pengukuran keakuratan hasil yang dicapai oleh model menggunakan teknik yang terdapat dalam aplikasi Weka yaitu confusion matrix dan cross-validation.

\subsection{Penarikan Kesimpulan}

Pada tahapan ini yaitu menyimpulkan hasil yang diperoleh dari penelitian dengan menggunakan Algoritma CART yang memberikan hasil akurasi terbaik untuk mendiagnosis penyakit diabetes mellitus berdasarkan nilai precision, recall, F-Measure dari tiap masing-masing algoritma dengan tingkat diagnosis sebagai berikut:

a. Excellent classification $=0.90-1.00$

b. Good classification $=0.80-0.90$

c. Fair classification $=0.70-0.80$

d. Poor classification $=0.60-0.70$

e. Failure $=0.50-0.60$

\section{HASIL DAN PEMBAHASAN}

\subsection{Identifikasi Masalah}

Dalam tahapan ini penulis melakukan beberapa studi pendahuluan dengan mempelajari literatur-literatur yang berkaitan dengan penelitian penulis yaitu untuk mendiagnosis penyakit diabetes retinopathy serta pemilihan algoritma yang sesuai untuk penelitian penulis ini. Dari hasil tersebut penulis melakukan penelitian dengan menggunakan algoritma CART untuk menganalisa dataset.

\subsection{Pengumpulan Data}

Dalam penelitian penulis ini data yang akan digunakan dalam penelitian yaitu dengan mengambil dari repository diambil dari database UCI repository. Dataset terdiri dari 1151 record, yang memiliki 19 attribute (18 attribute dan 1 attribute target). Attribute target terdiri dua output yaitu normal diabetes retinopathy dan terindikasi diabetes retinopathy [12]. kedua output pada class attribute ini akan digunakan ssebagai output data penyakit diabetes retinopathy. Data ini harus diolah terlebih dahulu yaitu melalui tahap pre-processing, dimana tahapan ini bertujuan untuk menyesuaikan atribut
- atribut yang akan digunakan dalam mengolah dataset tersebut karena setiap atribut pada dataset ini akan memberikan hasil yang berbeda - beda pada hasil akurasi dalam mendiagnosa penyakit diabetes retinopathy dan hal ini berkaitan ada atau tidaknya kelengkapan nilai pada setiap atribut. Atribut-atribut yang dimaksud adalah :

a. Attribute 0

Hasil biner dari penilaian yang berkualitas

b. Attribute 1

Hasil biner dari pre-screening

c. Attibute 2-7

Hasil dari deteksi MA.

d. Attribute 8-15

Eksudat yang diwakili oleh seperangkat, yang menghasilkan jumlah piksel yang membentuk lesi pada bola mata.

e. Attribute 16

Jarak euclidean dari pusat makula dan pusat cakram optik untuk memberikan informasi penting mengenai kondisi pasien.

f. Attribute 17

Diameter cakram optik.

g. Attribute 18

Hasil biner dari klasifikasi berbasis AM / FM

h. Class_Attribute

Label kelas. $1=$ mengandung tanda-tanda DR (label akumulatif untuk kelas Messidor 1, 2, 3), 0 = tidak ada tanda-tanda DR.

Atribut diatas yang digunakan peneliti untuk bahan penelitian dan terlebih dahulu disesuaikan dengan tipe data yang dapat dibaca oleh aplikasi Weka.

\subsection{Tahap Pre-Processing}

Dalam tahapan ini, dilakukan identifikasi dan penyesuaian atribut, serta penyeleksian dari datasetdiabetes retinopathy agar data yang diperoleh ialah data yang benar-benar siap untuk digunakan. Tabel 4, yang merupakan dataset diabetes retinopathy yang telah dilakukan penyesuaian atribut untuk aplikasi Weka. 
Tabel 4. Data Pre-Processing

\begin{tabular}{|c|c|c|}
\hline Data Asli & $\begin{array}{c}\text { Data Hasil } \\
\text { Pre-Processing }\end{array}$ & Keterangan \\
\hline 1 & 1 & $\begin{array}{l}\text { Hasil biner dari } \\
\text { penilaian yang } \\
\text { berkualitas }\end{array}$ \\
\hline 1 & 1 & $\begin{array}{l}\text { Hasil biner dari } \\
\text { pre-screening }\end{array}$ \\
\hline 22 & 22 & \multirow{6}{*}{$\begin{array}{l}\text { Hasil dari } \\
\text { deteksi MA }\end{array}$} \\
\hline 19 & 19 & \\
\hline 19 & 19 & \\
\hline 15 & 15 & \\
\hline 12 & 12 & \\
\hline 9 & 9 & \\
\hline $\begin{array}{c}70.19232 \\
4\end{array}$ & 70.192324 & \multirow{8}{*}{$\begin{array}{l}\text { Eksudat yang } \\
\text { diwakili oleh } \\
\text { seperangkat, } \\
\text { yang } \\
\text { menghasilkan } \\
\text { jumlah piksel } \\
\text { yang } \\
\text { membentuk lesi } \\
\text { pada bola mata. }\end{array}$} \\
\hline $\begin{array}{c}24.97133 \\
5\end{array}$ & 24.971335 & \\
\hline 4.403699 & 4.403699 & \\
\hline 0.713671 & 0.713671 & \\
\hline 0.394666 & 0.394666 & \\
\hline 0.207558 & 0.207558 & \\
\hline 0.089976 & 0.089976 & \\
\hline 0.039876 & 0.039876 & \\
\hline 0.518668 & 0.518668 & $\begin{array}{l}\text { Jarak euclidean } \\
\text { dari pusat } \\
\text { makula dan } \\
\text { pusat cakram } \\
\text { optik untuk } \\
\text { memberikan } \\
\text { informasi } \\
\text { penting } \\
\text { mengenai } \\
\text { kondisi pasien. }\end{array}$ \\
\hline 0.098155 & 0.098155 & $\begin{array}{l}\text { Hasil biner dari } \\
\text { klasifikasi } \\
\text { berbasis AM / } \\
\text { FM }\end{array}$ \\
\hline 1 & 1 & $\begin{array}{l}\text { Label kelas. 1 = } \\
\text { mengandung } \\
\text { tanda-tanda DR } \\
\text { (label } \\
\text { akumulatif } \\
\text { untuk kelas } \\
\text { Messidor 1, 2, } \\
\text { 3), } 0=\text { tidak ada } \\
\text { tanda-tanda DR }\end{array}$ \\
\hline $\begin{array}{c}\text { Contains } \\
\text { Signs }\end{array}$ & 0 & $\begin{array}{c}\text { Class, Contains } \\
\text { Signs }\end{array}$ \\
\hline Signs & 1 & Class, Signs \\
\hline
\end{tabular}

Dari hasil analisis tabel 4, tentang hasil data preprocessing dataset diabetes retinopathy yang telah dilakukan, bahwa semua atribut nilainya lengkap atau tidak missing value. Berikut ini merupakan tabel sebelum dan sesudah melalui proses penanganan missing value, dapat dilihat pada tabel 5 .

Tabel 5. Perbandingan Tabel Dataset Sebelum dan Sesudah Melalui Proses Penanganan Missing Value

\begin{tabular}{|c|c|}
\hline $\begin{array}{l}\text { Atribut Dataset } \\
\text { asli }\end{array}$ & $\begin{array}{c}\text { Atribut dataset setelah } \\
\text { melalui proses penanganan } \\
\text { missing values }\end{array}$ \\
\hline Attribute 0 & Attribute 0 \\
\hline Attribute 1 & Attribute 1 \\
\hline Attribute 2 & Attribute 2 \\
\hline Attribute 3 & Attribute 3 \\
\hline Attribute 4 & Attribute 4 \\
\hline Attribute 5 & Attribute 5 \\
\hline Attribute 6 & Attribute 6 \\
\hline Attribute 7 & Attribute 7 \\
\hline Attribute 8 & Attribute 8 \\
\hline Attribute 9 & Attribute 9 \\
\hline Attribute 10 & Attribute 10 \\
\hline Attribute 11 & Attribute 11 \\
\hline Attribute 12 & Attribute 12 \\
\hline Attribute 13 & Attribute 13 \\
\hline Attribute 14 & Attribute 14 \\
\hline Attribute 15 & Attribute 15 \\
\hline Attribute 16 & Attribute 16 \\
\hline Attribute 17 & Attribute 17 \\
\hline Attribute 18 & Attribute 18 \\
\hline $\begin{array}{c}\text { Target_Attribute } \\
19\end{array}$ & Target_Attribute 19 \\
\hline
\end{tabular}

\subsection{Penggunaan Metode Klasifikasi}

Setelah melalui tahapan pre-processing, selanjutnya dataset mulai diolah dengan menggunakan aplikasi Weka. Tahapan ini bertujuan untuk menghasilkan confusion matrix berdasarkan metode evaluasi 10-fold cross validation, dimana dataset tersebut dibagi menjadi 10 subsets $(9$ subsets sebagai trainingsets dan 1 subsets sebagai testingset) dengan jumlah 10 kali iterasi. Adapun classifier yang digunakan untuk uji coba pada dataset adalah SimpleCart (algoritma Classification And Regression Tress). Gambar 3 menunjukkan visualisasi data secara keseluruhan yang dijabarkan sesuai dengan atribut setelah melewati tahapan pre-processing. Selanjutnya data-data tersebut diklasifikasi menggunakan algoritma CART (SimpleCart dalam penggunaan pada aplikasi Weka) yang menghasilkan pola klasifikasi. Berikur gambar 3 tentang visualisasi data keseluruhan, sebagai berikut : 


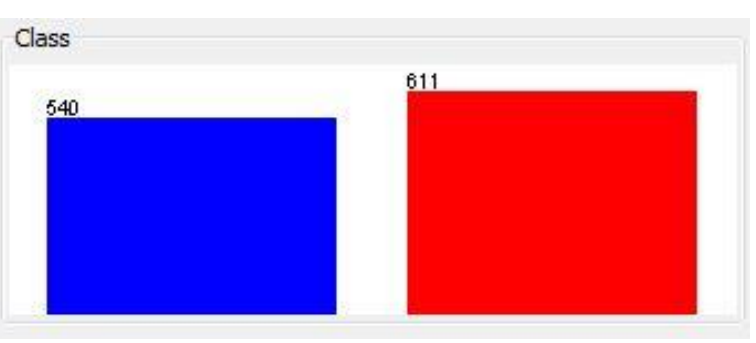

Gambar 3. Visualisasi data kesuluruhan

Keterangan dari gambar 3, diatas sebagai berikut:

a. Gambar grafik dengan warna biru terindikasi diabetes retinopathy.

b. Gambar grafik dengan warna merah normal atau tidak terindikasi diabetes retinopathy.

Hasil perhitungan dengan menggunakan aplikasi Weka didapatkan rule pohon keputusan dari dataset diabetes retinopathy yang dapat dilihat pada gambar 4. Pada pohon keputusan tersebut, dapat diketahui bahwa atribut 14 merupakan akar dari rule pohon keputusan. Jika pada atribut 14 nilainya kurang dari 0.0203705 , pada atribut 2 kurang dari 55.5, selanjutnya pada atribut 8 jika nilainya kurang dari 127.805703 maka class atributnya tidak terindikasi diabetes retinopathy.

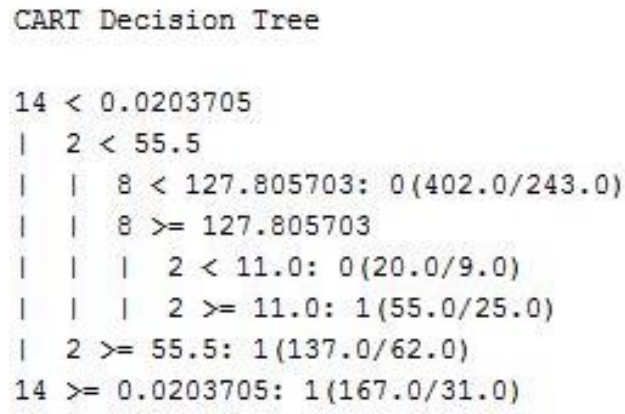

Gambar 4. Rule pohon keputusan dari dataset Diabetes Retinopathy

Kemudian jika nilai pada atribut 8 nilainya lebih dari 127.805703, selanjutnya pada atribut 2 nilainya kurang dari 11.0 maka class atributnya yatu tidak terindikasi diabetes retinopathy. Sedangkan jika pada atribut 2 nilainya lebih dari sama dengan 11.0 maka class atributnya adalah terindikasi diabetes retinopathy. Selanjutnya pada atribut 2 nilainya 55.5 maka class atributtnya adalah terindikasi diabetes retinopathy. Kemudian jika pada atribut 14 nilainya lebih dari sama dengan 0,203705 maka class atributnya terindikasi diabetes retinopathy. Pada algoritma pohon keputusan yang dihasilkan menggunakan algoritma CART yang terlihat pada gambar 5, menghasilkan nilai akurasi sebesar 63, 4231\%. Nilai akurasi tersebut didapatkan dari hasil perhitungan dari precision, recall dan $F$ Measure. Proses perhitungannya dapat dilihat pada tabel 6.

Tabel 6. Confusion Kelas " 0 "

\begin{tabular}{|c|c|}
\hline 368 (True positive) & 172 (False Negative) \\
\hline 249 (False Positive) & 362 (True Negative) \\
\hline
\end{tabular}

Pada tabel 6. Confusion Kelas "0",merupakan penjabaran dari confusion matrix yang dapat dilihat pada tabel 6.Confusion Kelas "0".

Kelas “0":

Precision $=\frac{\mathrm{TP}}{\mathrm{TP}+\mathrm{FP}}=\frac{368}{368+249}=0,596$

Recall $=\frac{\mathrm{TP}}{\mathrm{TP}+\mathrm{FN}}=\frac{368}{368+172}=0,681$

$F-$ Measure $=\frac{2 x \text { precision } \times \text { recall }}{\text { precision }+ \text { recall }}=\frac{2 \times 0,596 \times 0,681}{0,596+0,681}=$ $\frac{2 x 0,596 \times 0,681}{0,596+0,681}=\frac{2 x 0,405876}{1,277}=\frac{0,811752}{1,277}=0,636$

Tabel 7. Confusion Kelas "1"

362 (True Positive) 249 (False Negaitve)
172(False Positive) 368 (True Negative)

Kelas "1" :

Precision $=\frac{\mathrm{TP}}{\mathrm{TP}+\mathrm{FP}}=\frac{362}{362+272}=0,678$

Recall $=\frac{\mathrm{TP}}{\mathrm{TP}+\mathrm{FN}}=\frac{362}{362+172}=0,592$

F-Measure $=\frac{2 \times \text { precision } \times \text { recall }}{\text { precision }+ \text { recall }}=\frac{2 \times 0,678 \times 0,592}{0,678+0,592}=$ $\frac{2 x 0,401376}{1,27}=\frac{0,802752}{1,27}=0,632$

Dari hasil perhitungan diatas antara lain precision, recall dan F-Measure yang dihasilkan dari kelas 0 dan kelas 1 dapat dihitung nilai ratarata dari kelas-kelas yang ada (Weighted Avg) dengan terlebih dahulu menjumlahkan nilai $\mathrm{A}=$ $(368+172)=540$ dan nilai $\mathrm{B}=(249+362)=$ 611. Rumus untuk menghitung Weighted Avg, sebagai berikut:

Weighted Avg (precision) $=\frac{0,596 \times A+0,688 \times B}{1151}=$
$\frac{0,596 \times 540+0,688 \times 611}{1151}=\frac{321,84+420,368}{1151}=$
$\frac{742,208}{1151}=0,64$ 
Weighted Avg (recall) $=\frac{0,681 \times A+0,592 \times B}{1151}=$ $\frac{0,681 \times 540+0,592 \times 611}{1151}=\frac{367,74+361,712}{1151}=$ $\frac{729,452}{1151}=0,634$

Weighted Avg $(F$-Measure $)=\frac{0,636 \times A+0,632 \times B}{1151}=$ $\frac{0,636 \times 540+0,632 \times 611}{1151}=\frac{343,44+386,152}{1151}=$ $\frac{729,592}{1151}=0,634$

Hasil diatas merupakan perhitungan nilai akurasi berdasarkan confusion matrix yang disajikan pada tabel 8. Nilai akurasi berdasarkan confusion matrix, sebagai berikut:

Tabel 8. Nilai Akurasi Berdasarkan Confusion

\begin{tabular}{|c|c|c|c|}
\hline Class & Precision & Recall & $\begin{array}{c}F- \\
\text { Measure }\end{array}$ \\
\hline 0 & 0,596 & 0,681 & 0,636 \\
\hline 1 & 0,678 & 0,592 & 0,632 \\
\hline $\begin{array}{c}\text { Weighted } \\
\text { Avg }\end{array}$ & 0,64 & 0,634 & 0,634 \\
\hline
\end{tabular}

Pengklasifikasian untuk menguji dataset diabetes retinopathy dengan algoritma CART menggunakan aplikasi Weka 3.6 membutuhkan waktu 0,78 second.

\subsection{Validasi dan Evaluasi}

Untuk mengukur tingkat akurasi dari algoritma klasifikasi yang digunakan yaitu menggunakan confusion matrix yang disajikan pada tabel 9. Tabel tersebut merupakan tabel yang dihasilkan oleh confusion matrix dari pengujian dataset menggunakan algoritma CART dengan metode 10-fold cross validation.

Tabel 9. Confusion Matrix

\begin{tabular}{|c|c|c|}
\hline & $\begin{array}{c}\text { Normal } \\
\text { Diabetes } \\
\text { Retinopathy }\end{array}$ & $\begin{array}{c}\text { Terindikasi } \\
\text { Diabetes } \\
\text { Retinopathy }\end{array}$ \\
\hline $\begin{array}{c}\text { Normal } \\
\text { Diabetes } \\
\text { Retinopathy }\end{array}$ & 368 & 172 \\
\hline $\begin{array}{c}\text { Terindikasi } \\
\text { Diabetes } \\
\text { Retinopathy }\end{array}$ & 249 & 362 \\
\hline 1151 & 617 & 534 \\
\hline
\end{tabular}

Dari tabel 9, terlihat bahwa jumlah data hasil bentukan rule yang terkena penyakit diabetes retinopathy yang sama dengan data testing yang juga terkena diabetes retinopathy sebanyak 368 . Kemudian, jumlah data hasil bentukan rule yang tidak terkena diabetes retinopathy dengan data testing yang terkena diabetes retinopathy sebanyak 172. Selanjutnya, jumlah data hasil bentukan ruleyang terkena diabetes retinopathy dan data testing yang tidak terkena diabetes retinopathy sebanyak 249 . Terakhir, jumlah data hasil bentukan rule yang tidak terkena diabetes retinopathy yang sama dengan data testingyang juga tidak terkena diabetes retinopathy sebanyak 362 .

\subsection{Penarikan Kesimpulan}

Dari hasil perhitungan yang telah dilakukan pada algoritma CART didapatkan nilai akurasi yaitu $63.4231 \%$, dengan nilai precision $0.64 \%$, nilai Recall $0.634 \%$, dan nilai $F$-Measure 0,634\%. Grafik hasil akurasi dari perhitungan pada algoritma CART disajikan pada gambar 6.

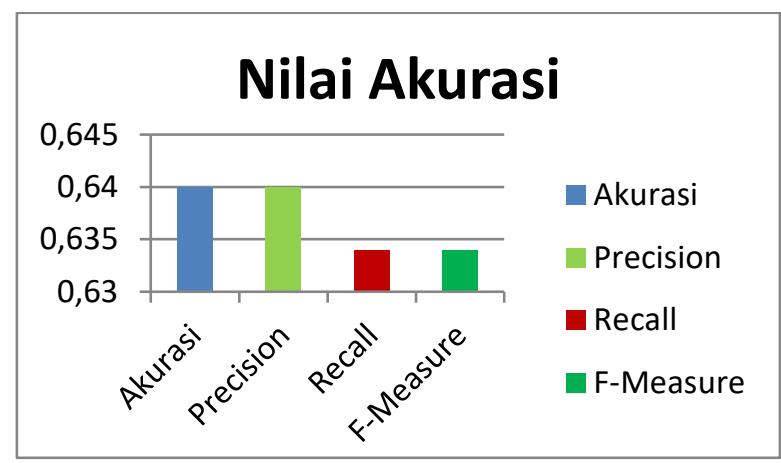

\section{SIMPULAN DAN SARAN}

4.1. Kesimpulan

Dari hasil penelitian ini, peneliti mengambil kesimpulan bahwa hasil analisis klasifikasi algoritma Classification And Regression Trees (CART) pada dataset diabetes retinopathy, berdasarkan dari nilai confusion matrix didapatkan hasil akurasi sebesar 63,4321\% dengan nilai precision $0.64 \%$, nilai Recall $0.634 \%$, dan nilai F-Measure 0,634\%.

\subsection{Saran}

1. Menambahkan algoritma klasifikasi untuk mengetahui bagaimana hasil akurasi yang lebih baik pada diagnosis penyakit diabetes retinopathy.

2. Melakukan seleksi fitur data mining pada algoritma dalam klasifikasi penyakit diabetes retinopathy. 
3. Peneliti berharap untuk penelitian selanjutnya, hasil analisis ini dapat diimplementasikan ke sebuah sistem.

\section{DAFTAR PUSTAKA}

[1] B. S. A. Ayu, Ratna Gitasari. Hidayat, "Klasifikasi Penyakit Diabetes Retinopati Berdasarkan Citra Digital dengan menggunakan Metode Wavelet dan Support Vector Machine.," Universitas Telkom, 2013.

[2] I. M. Dewi, "Mengenal Lebih Jauh Retinopathy Diabetik,” 2018. [Online]. Available:

https://www.columbiaasia.com/indonesia/heal th-articles/mengenal-lebih-jauhretinopathydiabetik.

[3] "Diabetik Retina: Pergeseran Paradigma Kebutaan pada Era Milenial." [Online]. Available:

http://www.yankes.kemkes.go.id/readretinopati-diabetik-pergeseran-paradigmakebutaan-pada-era-milenial-5984.html. Diakses Hari Selasa, 03 Maret 2020. Pukul 14.57 WIB.

[4] S. Faust, O., Acharya, R. U., Ng, E. Y. K., Ng, K. H. and J.S, "Algorithmsafor theaAutomated Detection ofaDiabetic Retinopathy Using Digital FundusaImage : A Review," JaMed Syst, 2010.

[5] IDF., "Diabetes Melitus Atlas," Sixth Edition, 2013. [Online]. Available: http://www.idf.org/Diabetes
Melitusatlas/download-book.Di akses Pada Hari Selasa, 03 Maret 2020. Pukul 15.04 WIB.

[6] and D. . S. Christobel, Angeline, “'An Empirical Comparison of Data Mining Classification Methods," 201AD, pp. 24- 28.

[7] E. Prasetyo, Data Mining Konsep dan Aplikasi Menggunakan Matlab. Yogyakarta: Andi Offset, 2012.

[8] W. B. Komalasari, "Metode Pohon Regresi Untuk Eksplorasi Data Dengan Peubah Yang Banyak Dan Kompleks," J. Infomatika Pertan., vol. Volume 16, 2007.

[9] Nuriyah, "Perbandingan Metode chi-square automstic interaction detection (chaid) dan classification and regression tree (cart) Dalam Menentukan Klasifikasi Alumni UIN Sunan Kalijaga Berdasarkan Masa Studi," Universitas Islam Negeri Sunan Kalijaga, 2013.

[10] R. Timofeev, Classification and Regression Trees (CART) Theory and Aplications. Berlin: Humboldt University, 2004.

[11] D. Susanto, S., dan Suryadi, Pengantar Data Mining. Yogyakarta: Andi Offset, 2010.

[12] "Machine Learning Repository," 2018. [Online]. Available: https://archive.ics.uci.edu/ml/datasets/Diabetic +Retinopathy+Debrecen+Data+Set\#.

[13] M. Han, J., \& Kamber, Data Mining Concepts, Model and Techniques 2nd Edition. San Fransisco: Elsevier, 2006. 